Дергачова В.В.

доктор економ. наук, професор

Колешня Я.О.

Національний технічний університет України «КПІ»

\title{
РОЛЬ ЕКОНОМІЧНОЇ БЕЗПЕКИ МАЛИХ ТА СЕРЕДНІХ ПІДПРИЕМСТВ В ЕКОНОМІЧНІЙ БЕЗПЕЦІ ДЕРЖАВИ
}

\author{
РОЛЬ ЭКОНОМИЧЕСКОЙ БЕЗОПАСНОСТИ МАЛЫХ И СРЕДНИХ \\ ПРЕДПРИЯТИЙ В ЭКОНОМИЧЕСКОЙ БЕЗОПАСНОСТИ СТРАНЫ
}

\author{
THE ROLE OF THE ECONOMIC SECURITY OF SMALL AND MEDIUM \\ ENTERPRISES IN THE ECONOMIC SECURITY OF THE COUNTRY
}

Проаналізовано значення малого та середнього підприємництва (МСП) $у$ економічній системі європейських краӥн та Украӥни, визначено частку малого бізнесу у структурі суб'єктів господарювання держави, продемонстровано його роль як основи конкурентного середовища, провідника наукового-технічного прогресу, засобу зниження рівня безробіття, сприяння покращенню соџіального клімату у суспільстві та створення ринку якісної продукиії та послуг. Окреслено причини, щуо негативно впливають на розвиток МСП в Україні, серед яких складність доступу до фінансових ресурсів, несприятливий клімат для ведення бізнесу, недосконалість законодавства тощо. Освітлено фактори, щзо впливають на економічну безпеку підприємства: недосконалість конкурентного середовища, високий рівень тонізащії економіки, залежність від органів влади у вирішенні низки проблем, низький рівень розвитку економіки в цілому, політичні проблеми. Продемонстровано взаємозв'язок між економічною безпекою держави та малого та середнього підприємництва, щзо проявляється у їх діалектичній єдності. Визначено роль підприємия та держави $у$ забезпеченні економічної безпеки підприємництва.

Ключові слова: мале та середнє підприємництво, економічна безпека підприємництва, принципи системи економічної безпеки підприємництва.

Проанализировано значение малого и среднего предпринимательства (МСП) в экономической системе европейских стран и Украины, определена доля малого бизнеса в структуре субъектов государства, продемонстрировано его роль как основы конкурентной среды, проводника научного-технического прогресса, средства снижения уровня безработицы, содействие улучшению сочиального климата в обществе и создание рынка качественной продукиии и услуг. Определены причины, негативно влияющие на развитие МСП в Украине, среди которых сложность доступа к финансовым ресурсам, неблагоприятный климат для ведения бизнеса, несовершенство законодательства и тому подобное. Освещены факторы, влияющие на экономическую безопасность предприятия: несовершенство конкурентной среды, высокий уровень тонизирования экономики, зависимость от органов власти в решении ряда проблем, низкий уровень развития экономики в иелом, политические проблемы. Продемонстрировано взаимосвязь между экономической безопасности государства и малого и среднего предпринимательства, 
проявляется в их диалектическом единстве. Определена роль предпринимателя и государства в обеспечении экономической безопасности предпринимательства.

Ключевые слова: малое и среднее предпринимательство, экономическая безопасность предпринимательства, принципы системы экономической безопасности предпринимательства.

The article analyses the importance of small and medium-sized enterprises (SMEs) in the economic system of European countries and Ukraine, determines the role of small businesses in the structure of business entities, demonstrates its role as the foundation of competitive environment, as the conductor of scientific and technical progress, as an instrument of reducing unemployment, improvement of the social climate in society and creation of a market of quality products and services. It determines reasons affecting the development of SMEs in Ukraine including the difficult access to financial resources, a disadvantageous business climate, imperfect legislation and others. It highlights factors affecting the economic security of the enterprise: the imperfection of the competitive environment, high levels of toning the economy, dependent on the authorities in solving a number of problems, a low level of economic development in general, political issues. The link between economic security and small and medium enterprises which manifested in their dialectical unity is demonstrated. The role of the entrepreneur and the government in provide economic security business is defined.

Keywords: small and medium-sized entrepreneurship, economic security of entrepreneurship, principles of economic security of the enterprise.

Вступ. Економіка України сьогодні знаходиться в украй важкому стані. Дестабілізуючий вплив на неї мають цілий ряд негативних чинників - це i політичні причини, і напружені зовнішньоекономічні відносини, реформи, деякі 3 яких мають негативний вплив в короткостроковому періоді, проте котрі покликані сприяти в майбутньому інтеграційним процесам 3 СС, зростання зовнішнього боргу та загрози дефолту. В таких умовах дуже важливо контролювати економічну безпеку держави. Проте економічна безпека - це стан рівноваги і розвитку національної економічної системи, яка, як і будь-яка система складається з певних елементів. Ключовими елементами в даному випадку виступають суб'єкти господарювання i, як ключовий (оскільки найбільш чисельний) елемент - малі та середні суб'єкти господарювання, тобто мале та середнє підприємництво (МСП). Саме тому контроль економічної безпеки МСП $є$ головною запорукою забезпечення економічної безпеки держави в цілому.

Питання економічної безпеки МСП досить широко розглядається науковцями, проте основна увага приділяється державному забезпеченню економічної безпеки, в той час як дана проблема повинна вирішуватись комплексно, враховуючи тісну діалектичну єдність понять «економічна безпека підприємництва» та «економічна безпека держави».

Постановка завдання. Метою даної роботи є виявлення ролі МСП в економічній системі країни, висвітлення взаємозв'язку економічної безпеки 
МСП та економічної безпеки держави в цілому, а також обгрунтування необхідності комплексного підходу у забезпеченні економічної безпеки МСП.

Методологія. В роботі використано загальнонаукові та статистичні методи: аналіз останніх публікацій з обраної проблематики, синтезу положень окремих робіт, порівняння ролі МСП в Україні та європейських державах, аналіз статистичних даних щодо структури суб'єктів господарювання, оцінка економічного впливу малого і середнього бізнесу на соціально-економічну ситуацію в країні, аналіз джерел несприятливого впливу на МСП в Україні, аналіз впливу державної політики на МСП, оцінка ролі власників та державних органів влади у забезпеченні економічної безпеки малих та середніх підприємств.

Результати дослідження. Сьогодні мале та середнє підприємництво (МСП) - це основа господарства будь-якої розвиненої країни Європи. Так, у ЄС близько 99\% підприємств належать до малого та середнього бізнесу [1, с. 177]. Сектор МСП у секторі бізнесу забезпечував роботою 2-х працівників 3 кожних 3-х и генерував 58 центів 3 кожного євро доданої вартості. В абсолютних показниках сектор МCП в EU-27 давав роботу 88.8 мільйонам людей та генерував $€ 3,666$ трильйонів євро доданої вартості. Подібні показники демонструє сектор МСП і в США, що визначає той факт, що сектор МСП у США визнається одним з ключових факторів національної безпеки [2].

Значення малого та середнього підприємництва в Україні теж важко переоцінити - станом на 2014 рік МСП складало 99,97\% у структурі суб'єктів господарювання за розміром (рис. 1).

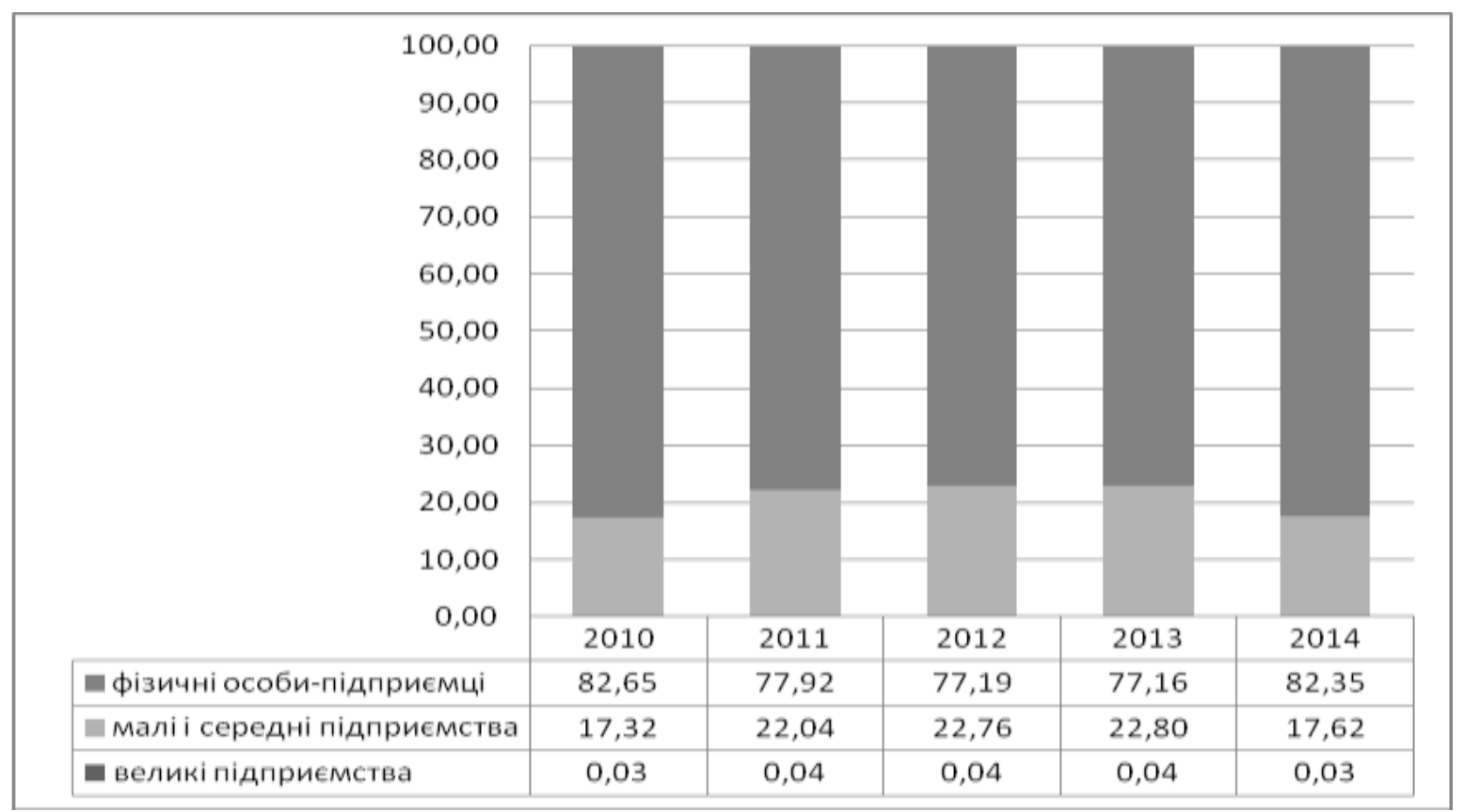

Рис. 1. Структура суб'єктів господарювання за розмірами в 2010-2014 pp. Джерело: [3] 
МСП в Україні за даними податкової служби з 2008 року стабільно забезпечують надходження до державного бюджету біля 50\% загальних податкових надходжень та більше $60 \%$ надходжень від податку на додатну вартість. Експертні оцінки щодо частки МСП у ВВП України дорівнюють біля $50-60 \%$ [2].

МСП в Україні лише у секторі підприємств (без фізичних осібпідприємців) забезпечують робочими місцями біля 70\% працюючих у секторі бізнесу (крім фінансового сектору). За даними Державної служби статистики України у 2013 році лише на малих і середніх підприємствах (без фізичних осіб-підприємців) кількість найманих працівників складала $67,3 \%$ від загальної кількості найманих працівників [2].

Таким чином, сьогодні саме МСП є тією основою, які в цілому формує картину економічних відносин в країні, відображає стан їх розвитку та виступає основою розвитку країни і цілому. Роль малого та середнього підприємництва проявляється у наступному:

- забезпечення робочих місць та зниження рівня безробіття в країні за рахунок як створення робочих місць, так і за рахунок само зайнятості (у випадку ФОП-суб'єктів мікропідприємництва, тобто у випадку сімейних домогосподарств, де власник $є$ єдиним працівником, або ж працівниками $є$ лише члени його сім'ї);

- формування конкурентного середовища. МСП за своєю природою $\epsilon$ антимонопольною формою господарювання, що пов'язано в першу чергу $з$ різноманіттям його форм. Водночас, МСП, маючи вузьку спеціалізацію, має більше можливостей до використання нових технологій, висапуючи таким чином відчутним конкурентом навіть для великих корпорацій;

- малий бізнес оперативно реагує на зміни кон'юнктури ринку, надаючи ринковій економіці необхідної гнучкості [4];

- МСП виступає провідником науково-технічного прогресу (НТП). Саме у цьому секторі економіки реалізуються новітні комерційні та технологічні ідеї. Так, у США саме на цей сектор припадає близько 50\% науково-технічних розробок [4];

- можливість швидко реагувати на зміни в економіці та впроваджувати нові системи управління та функціонування в цілому. Завдяки своїм масштабам та відсутності заплутаних міжпідроздільних зв'язків 
невеликі підприємства здатні швидко реагувати на зовнішні впливи та гнучко змінюватися задля їх прийняття або знешкодження;

- сприяння створенню середнього класу i, таким чином, зниження соціального напруження та сприяння позитивному соціальному клімату і зростання добробуту населення країни;

- виведення на ринок якісного, конкурентного продукту. Чисельність підприємств малого бізнесу зумовлює пошук засобів завоювання частки ринку неціновими методами, а тому сприяє підвищенню якості створюваного продукту чи наданої послуги, створення нових продуктів чи послуг, задоволення специфічних запитів споживача (наприклад, виробництво екологічно чистих продуктів тощо).

Таким чином, МСП відіграє значну роль в господарській системи будьякої країни. Виступаючи не лише найбільш чисельним елементом економічної системи держави, а й найбільш гнучким та динамічним, воно значною мірою визначає рівень її розвитку. Маючи змогу найбільш оперативно реагувати на негативні дестабілізуючі впливи, малий бізнес має найбільше шансів на збереження стабільності економіки країни в цілому. Це пов'язано перш за все 3 відсутністю потреби у значних початкових інвестиціях, швидким обертанням ресурсів, а також з простотою функціональних зв'язків.

Проте розвиток сектору малого підприємництва в Україні стримується низкою причин:

- відсутність легкого доступу до джерел фінансування. Кредитування малого підприємництва в нашій країні майже відсутнє;

- складність реєстрації малого бізнесу. Згідно 3 даними Групи Всесвітнього банку, в рейтингу Doing Business, за складністю реєстрації підприємств Україна на 2015 рік займала 70 місце. Проте зміни в законодавство дали змогу піднятися в цьому рейтингу одразу на 40 пунктів (на 2016 рік 30-е місце) [5]. Для порівняння в 2011 році це була 116 позиція;

- нестабільність законодавства. Особливо це виявляється в останній час, коли законодавство зазнає частих (і не завжди позитивних для МСП) змін на фоні приведення правового поля України у відповідність 3 вимогами Угоди про асоціацію між Україною та Європейським Союзом; - недосконалість партнерства між малим бізнесом та державою [6]. Взагалі державна підтримка малого бізнесу в Україні є надзвичайно слабкою. 
Враховуючи все вищесказане, на сьогодні Україна займає 87 місце з 189 за сприятливістю ведення бізнесу [5].

В той же час важливість МСП для економіки (особливо перехідної) яскраво відображається на прикладі Польщі. Саме цей сектор став основою антикризової програми уряду, мінімізував наслідки ліквідації державного сектору економіки. На сьогодні МСП складає близько 50\% ВВП [1, с. 177].

Малий бізнес для економіки України відіграє важливу роль. Великі підприємства здебільшого володіють застарілою матеріально-технічною базою і не мають достатніх фінансових ресурсів для ï оновлення. Рівень збитковості великих та середніх підприємств в України за даними Державної служби статистики за січень-червень 2015 року склав 57,3\%, тобто більше половини таких господарюючих суб'єктів є збитковими. Це свідчить про те, що найбільш ефективними в сьогоднішніх умовах ведення господарської діяльності є саме малі підприємства та ФОП. I саме вони потребують найбільшої державної підтримки в умовах необхідності підтримання економіки держави. На сьогодні було зроблено ряд позитивних змін, зокрема внесено зміни до Податкового Кодексу (зниження податкових ставок, запровадження мораторію на перевірки бізнесу, запроваджено механізм електронних перевірок) [1, с.178].

Проте ці заходи не $\epsilon$ достатніми для забезпечення ефективного функціонування та подальшого стійкого розвитку даного сегменту. В сучасних економічних умовах особливої гостроти набуло питання підтримання того стану захищеності корпоративних ресурсів та підприємницьких можливостей, який би давав змогу підприємству припиняти негативний вплив зовнішнього середовища i створювати умови для ефективного функціонування підприємства, тобто підтримання економічної безпеки підприємства [7, с. 108].

Недосконалість конкурентного середовища, корупційні процеси та схеми, високий рівень тінізації економіки, котрі сьогодні ми можемо спостерігати, негативно впливають на економічну безпеку підприємництва. Водночас підприємництво залежить і від рівня розвитку підприємництва в державі, обсягів виробництва та реалізації продукції, конкурентоспроможності регіонів та економіки в цілому [7, с. 107-108].

Рівень економічної безпеки підприємництва включає [7, с. 108]:

1) рівень економічної незалежності підприємства (забезпеченість ресурсами, відповідною матеріально-технічною базою); 
2) рівень економічної ефективності функціонування підприємства;

3) здатність до подальшого розвитку (оскільки ціль будь-якої господарської діяльності не може обмежуватися лише утриманням наявного рівня прибутковості, рентабельності тощо, а й включає формування резервів та можливостей до подальшого розвитку та зростання).

Враховуючи значення малого підприємництва в економіці держави, можна говорити про значний вплив економічної безпеки підприємництва на економічну безпеку країни в цілому. Безпечне підприємницьке середовище це основа соціально-економічного розвитку країни, а тому саме на його створення та підтримання має бути спрямована значна увага. Водночас ключову роль відіграє контроль та підтримання економічної безпеки найменшої ланки економічної системи - суб'єкта підприємництва. Це завдання лягає в першу чергу на плечі керівника чи безпосереднього власника того чи іншого підприємства. Так, найважливішим елементом економічної безпеки підприємства $є$ фінансова безпека, котра в свою чергу залежить від показників ефективності діяльності підприємства, зростання потенціалу, забезпечення стійкості та розвитку, формування резервних фондів тощо.

Проте існує ряд проблем, вирішення яких неможливе силами підприємця. Так, опитування, проведене серед керівників, власників та фахівців суб'єктів малого підприємництва, показало, що на їх інтереси найбільшою мірою впливають відносини 3 владою та діяльність злочинних структур [8]. Ці проблеми проявляються перш за все у витратах на ведення бізнесу, але вирішуватися можуть лише на державному рівні.

Підприємці, котрі прагнуть підвищити рівень економічної безпеки, повинні підвищувати власну конкурентоспроможність в тому числі і за рахунок впровадження нових ресурсозберігаючих технологій, таким чином збільшуючи рівень конкурентоспроможності економіки в цілому та сприяючи оновленню матеріально-технічної бази виробництва у більшому масштабі. Водночас рівень проникнення розробок науково-технічного прогресу в економічну діяльність в масштабах країни визначає їх доступність на рівні окремого малого підприємства та можливість залучити їх за мінімальними затратами.

Як бачимо, в цих моментах проявляється діалектична єдність економічної безпеки держави та економічної безпеки підприємництва. Таким чином, можна говорити лише про комплексний підхід у забезпеченні економічної безпеки підприємства як ключового елемента економічної 
безпеки країни в цілому. Принципи системи економічної безпеки підприємництва у контексті зміцнення безпеки держави зображено на рис. 2 .

Як бачимо, роль держави у забезпеченні економічної безпеки МСП, незважаючи на значну їх здатність пристосовуватися до умов господарювання в країні, залишається значною. Адже саме на державному рівні розробляються і впроваджуються фундаментальні основи підприємництва - від законодавчої бази до формування стратегій розвитку господарства в цілому. Саме на державному рівні формуються такі важливі фактори, котрі часто визначають і галузь, у якій буде функціонувати підприємство, і принципи його створення та подальшої діяльності, як політика оподаткування, фінансування галузей та надання дотацій, зовнішня політика, антимонопольна політика тощо.

Малий та середній бізнес, хоча і має вплив на соціально-економічну ситуацію в країні, проте в такій же мірі і залежний від неї, адже на сприятливість ведення бізнесу (a, отже, і можливість його ведення безпечно, тобто забезпечуючи достатній рівень економічної безпеки бізнесу) в значній мірі впливають вищенаведені фактори. Водночас, уникнути їх або підлаштуватися малий та середній бізнес не завжди має можливість. 


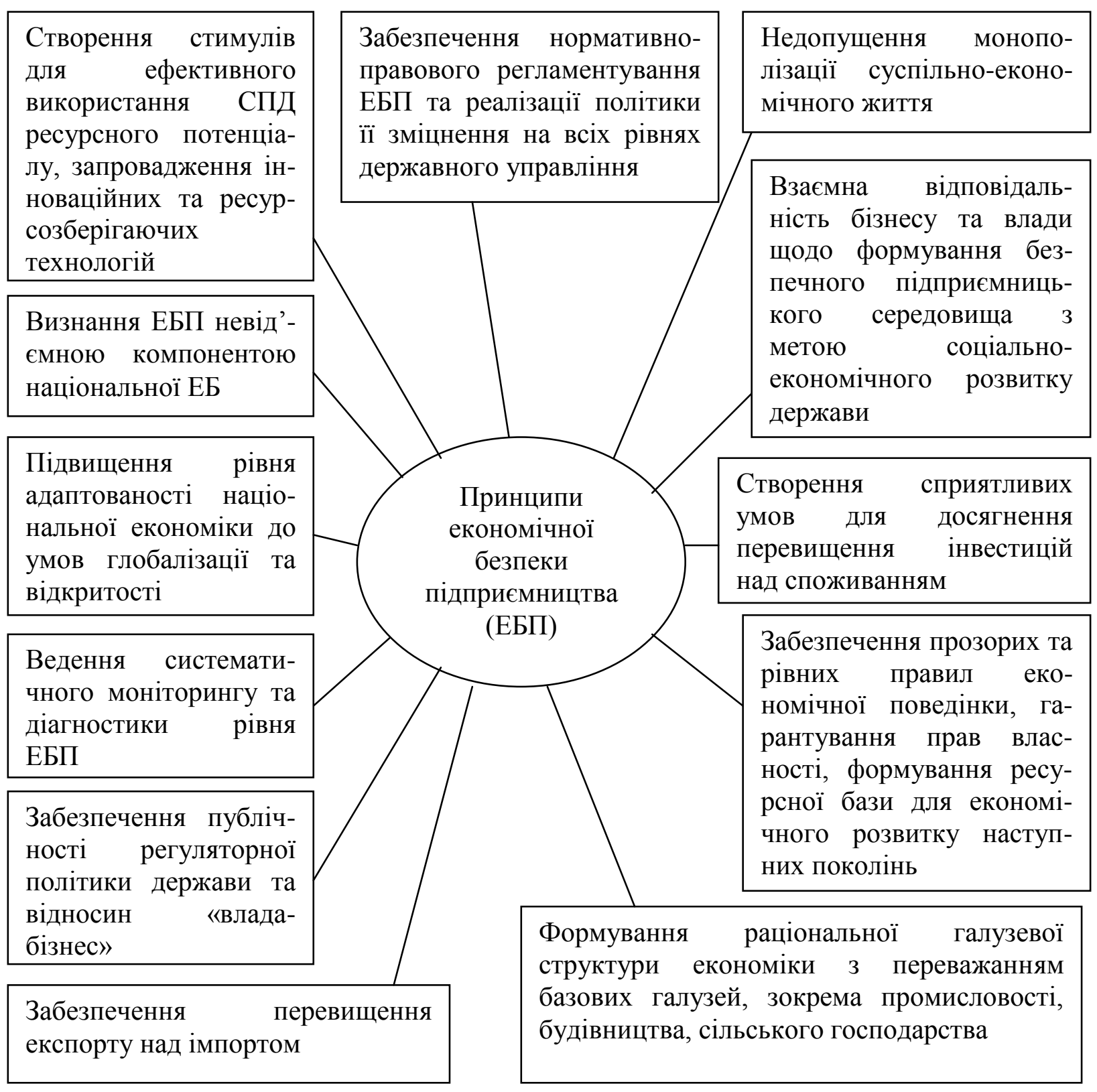

Рис. 2. Принципи системи економічної безпеки підприємництва у контексті зміцнення безпеки держави

Джерело: [8]

Саме тому в забезпеченні економічної безпеки МСП велику роль відіграє в тому числі і державна політика. Можна говорити про те, що забезпечення економічної безпеки малого та середнього бізнесу $є$ завданням одразу кількох рівнів - безпосередньо рівень самого підприємства (в особі директора чи власника), місцевого (в особі місцевих органів влади, що визначають напрямки розвитку регіону чи окремого населеного пункту) та загальнодержавного (в особі державних органів влади). 
Сучасні умови функціонування підприємств в Україні значно ускладнені рядом дестабілізуючих факторів: політична ситуація, економічна ситуація (особливо на фоні проведення АТО), проведення реформаційних процесів з метою виконання вимог Угоди про асоціацію з СС, незадовільний стан банківської системи та іï перебудова, відсутність коштів у дебіторів та неможливість знайти джерела фінансування, низький рівень іноземного інвестування тощо. Всі ці процеси негативно впливають на стан економічної безпеки держави та підприємництва. Враховуючи роль МСП та рівень їх впливу на соціально-економічний стан країни, особливого значення набуває саме економічна безпека малих та середніх підприємств, іiі постійний моніторинг та побудова ефективної системи ії управління.

Висновки. Наукова новизна даної роботи полягає у висвітленні ролі МСП в господарській системі нашої країни як головного елемента, що сприятиме виходу 3 кризи в сучасних складних соціально-економічних умовах. На даній основі відображено важливість комплексного підходу до забезпечення економічної стійкості суб'єктів малого та середнього підприємництва та обгрунтовано необхідність залучення держави до даного процесу.

Дана стаття узагальнює ключові положення щодо МСП в Україні - його частка та роль в господарстві країни, пояснює важливість економічної безпеки МСП як ключового елемента господарства та необхідність управління економічною стійкістю МСП та визначає роль держави як одного з суб'єктів, що можуть впливати на економічну стійкість МСП шляхом проведення виваженої політики, особливо 3 урахуванням складності ведення господарської діяльності у зв'язку з проведенням реформаційних процесів в Україні.

Мале та середнє підприємництво $\epsilon$ ключовою ланкою будь-якої розвиненої країни світу, що можна побачити на прикладі країн Євросоюзу. До того ж, при правильному підході до проведення реформаційних процесів, саме ці суб'єкти господарювання можуть стати тією базою, що дасть змогу подолати кризові явища (як у Польщі). Україна за показниками частки МСП в структурі суб'єктів господарювання відповідає країнам ЄС. Так, на долю великих підприємств припадає лише $0,04 \%$, в той час як мікро-субєкти господарювання (ФОП та мікро-підприємства) становлять більше 77\% господарюючих суб'єктів. 
Враховуючи значний вплив на економіку країни, що проявляється не лише у значній долі ВВП, а й у здатності малого бізнесу виступати ефективним засобом вирішення цілого ряду соціально-економічних проблем (безробіття, значна напруженість соціального клімату у суспільстві, каталізатор НТП тощо), складно переоцінити його значення як ключового елемента господарської системи України.

Водночас державі необхідно забезпечувати економічну безпеку, а враховуючи вищесказане це можливо лише за умови забезпечення економічної безпеки саме ключової ланки - малого і середнього бізнесу. Проте водночас підтримання будь-якого підприємництва потребує позитивного соціально-економічного клімату в країні, щоб забезпечувати інфраструктурні, фінансові, правові та інші основи функціонування підприємства. Саме у цьому проявляється взаємозалежність та взаємопроникність понять «економічна безпека підприємництва» та «економічна безпека країни», а тому забезпечення економічної безпеки МСП потребує поєднання місцевих (на рівні підприємства) та загальнодержавних (на рівні місцевих та вищих органів влади) підходів.

Подальші дослідження необхідно спрямовувати в першу чергу на засоби та способи аналізу та управління економічною стійкістю МСП на рівні суб'єкта господарювання та на рівні держави, визначення шляхів збалансування цих видів управління економічною стійкістю, а також на розробку механізму управляння економічною стійкістю МСП.

\section{Література:}

1. Садова У. Шляхи активізації розвитку малого бізнесу в Україні / У. Садова. // Актуальні проблеми функціонування господарської системи України: Матеріали XXII-гої міжнародної наукової конференції студентів, аспірантів та молодих учених, Львів, 15 травня 2015 р. - Львів: ЛНУ імені Івана Франка, 2015. - С.177-178

2. Засади дерегуляції в Україні [Електронний ресурс] - Режим доступу: https://dimitrioliapin.wordpress.com/2014/10/27/засади-дерегуляції-в-україні/

3. Показники структурної статистики по суб’єктах господарювання з розподілом за їх розмірами [Електронний ресурс] - Режим доступу: http://www.ukrstat.gov.ua/operativ/operativ2012/fin/osp/osp_u/osp_u.htm.

4. Сумський С.А. Роль і місце малого бізнесу в механізмі забезпеченні економічної безпеки України [Електронний ресурс] - Режим доступу: http://eprints.cdu.edu.ua/452/1/conf_odesa_2015.pdf\#page=98

5. Благоприятность условий ведения бизнеса: Украина [Електронний ресурс] - Режим доступу: http://russian.doingbusiness.org/data/exploreeconomies/ukraine/. 
6. Мілашенко Т. Т. Проблеми розвитку підприємництва в Україні [Електронний pecypc] Режим доступу: http://kaliningrad.ruc.su/upload/medialibrary/4c6/npsADEE.pdf\#page=169

7. Козак Л.С. Формування системи економічної безпеки підприємництва як об'єктивна передумова розвитку національної економіки [Електронний ресурс] - Режим доступу до pecypcy: http://journals.uran.ua/index.php/2075-4892/article/view/51124/47149.

8. Васильців Т.Г. Форування середовища економічної безпеки підприємництва в Україні [Електроннй ресурс $]$ Режим доступу: http://www.ceeol.com/aspx/getdocument.aspx?logid=5\&id=ba02a238d26745a781d9e3f15038dc1 9 